\title{
Searching For Certitude: A Study of Zahida Zaidi's Burning
} Desert

\author{
Dr. Md. Habib Subhan \\ Department of English, Aligarh Muslim University, India
}

\begin{abstract}
Liberation of British colonies and disintegration of Soviet Union changed the world power structure and it was expected that this new world order will give a new lease of life to world civilization. Much to our expectation, cultural struggle continued to regulate the relationship of the west and east. After 1980s onward the Middle East occupied the western imagination. A horrified spectacle of American imperialism took the centre stage. South Asian literature pins down the growing assertion of European imperialism in the Middle East and criticizes the changing form of exploitation of the weaker nations. The present paper is an attempt to investigate the continuation and perpetuation of colonial othering by the western nations in order to suit their greater interest and to look into the possibility of peace, serenity and sanity amidst chaos and organic flow of power in the society as projected in the famous play Burning Desert of Sahitya Academy Award wining author Zahida Zaidi.
\end{abstract}

Keywords: Colonialism, Displacement, Imperialism, Othering, Power and South Asian Literature.

It is indeed a matter of critical scrutiny that the emergence of drama as an art form has shown an acute experiment in the matter of stagecraft, themes and characters and plot. A larger part of English drama of fifteen or sixteen century, shows a tendency to focus on the characters who are made to act within the broader change brought by the European enlightenment. The playwrights of this period have imbibed their characters with the ethos of enlightenment. Therefore, the central characters of the Shakespeares' Hamlet and Macbeth or of Marlow's Faustus act throughout the play as an enlightened man caught in the whirlwind of moral dilemmas as in the case of Hamlet and Macbeth and of excessive thirst for knowledge as in the case Faustus. As a matter of fact, literature cannot be rescued from the influences or impact of movements of that time of which a text is a product. Therefore, if Renaissance or Enlightenment continued to influence the literary production of fifteen or sixteen century, colonialism and imperialism continued to preoccupy the writers of the colonies. Literature produced by the writers during colonial time mainly focuses on the cultural dislocation, dehumanization of native, socio-economic disintegration, division of country on religious, regional and racial line, and the rise of counter resistance in reaction to deep rooted colonial othering. However, post-colonial period writings reveal the writers' preoccupation with the horror of partition of the country (India) and a tendency to rebuild the nation from the damages wrought by colonialism. Celebration of indigenous culture, identity, language etc. constitutes the major themes of literature of this period. But independence could not liberate the colony from the European obsession with the East and therefore, colonialism manifests itself in the form of neo-colonialism or neoimperialism of America. In the name of creating a democratic world order, the developed European nations devised their ideology to control the weaker nations.

A keen observer of the historical chronicle, Zahida Zaidi gives us an insight into the changing mode of colonialism in her play Burning Desert published in 1998. In doing so she has shown the continuity of colonial legacy in the neo - colonialist approach of the developed European nations. However, it would supersede the multiple angles of the play if it is approached simply as a historical narrative dealing the changing form of colonialism and imperialism. The depiction of futility of individual action in search of a centre in a centreless world, the allegorical style of dealing with the moral and spiritual crisis of man in a politically hostile world and its elegiac note on the death of individualism adds comprehensive dimension to the play.

Using Gulf War as the background, the author unravels the fictional history through the central characters of the play and creates a horrified spectacle of violence, cruelty and torture. In fact, in its description of the horrified spectacle of bloodshed and damages, the play truly reflects the ethos of Theatre of Cruelty and holocaust literature. The development of plot in which the Central character Cactus guided by unflinching desire of power delves into bloody battle with the inferior nations speaks out the hidden ideology of the West. The decolonization turned to be a futile exercise for many of the nations as the Western Nations continued to perpetuate their theory of annexation and divide and rule in the Middle East. The loss of power of Britain was a gain for United States of America but this change in the dichotomy of power did not worsen the relationship of Britain and America. Instead there seems to be a common understanding of being one while it is a question of West verses East. Consequently, the excessive zeal for final authority over the inferior sovereign nations 
necessitated the exercise of mass weapons of destruction. Cactus, the central character of the play, has excessive desire for controlling the world with the assumption and intention to create a New World Order. The author very artistically brings out the parallel development of history and fiction. As a political allegory, the play brings out the picture of Gulf War through the clash of interest between Cactus and Berham. It is interesting to note that Zaidi sets a trend in the theatre world by making her protagonist a villain - very shrewd, cunning and ruthless. Cactus's obsession with Behram's Kingdom reveals the imperial desire of the United States of America to have control over the natural resources of the Middle East. This desire revived their open hostility against Behram. It is not that Cactus really wants to tranquilize the growing hostility of Behram with the surrounding kings. Instead his real intention is to destroy the growing possibility of peaceful settlement of internal problems of the surrounding regions so that he can assert his power over these nations. Much of Zaidi's premises on the concept of power are Foucauldian in nature

Zaidi grounds her concept of power on Michael Foucault's notion of power. Cactus very much believes that the exercise of power depends on a discourse that legitimizes the use of power. Therefore, he engages people in creating a discourse that produces a positive self image at the cost of negative portrayal of his enemy Behram. It is not that Cactus was born powerful but it is the consent of all other kings which makes him more powerful. He created divisions and frictions among the kings of different states on the one hand and Behram on the other hand. Zaidi believes that:

"Power must be analyzed as something which circulates, or as something which only functions in the form of a chain...Power is employed and exercised through a net like organization...Individuals are the vehicle of power, not its points of application." (Foucault 1980:98 $)^{1}$

In substantiating her notion of power she posits Cactus as an agent of power who enacts power over Behram. The climax as drawn by Zaidi weaves the web like structure of power through polarization of parties. Cactus managed to persuade the enemies of Behram to stand by him. In a typical colonial fashion he posits himself as the savior who will bring Behram down and will bring peace and new world order. He created the discourse that inferior nations cannot fight back another inferior nation and therefore these inferior nations should look towards the superior nations. This myth generated a consensus among the allies of Cactus and swayed them by the idea of becoming superior nation in the company of Emperor Cactus. Nawab Alsafa Albaqa says:

Under your noble protection, I shall establish my kingdom. The ruins will be turned into palaces and pleasure houses and I shall rule over the decaying corpses and well-fed vulture with great pomp and show. And shall be always loyal to you, and my children and great grand children, too, would be loyal to you and always pray for your well-being (Burning Desert:25) ${ }^{2}$

Zaidi while treating the approaching war between Cactus and Berham transcends boundaries and brings out the possible impact of such war in the developing nations. Cactus farfetched ideology aims at achieving dual purposes - to have the control over Berham's country and to curb the defying heads that poses threat to his supremacy. He realized that so long as Behram controls these nations, the prospect of entering into these territories is bleak. Thus, by waging a bloody war he wants to annihilate and dismantle the control of inferior Behram over his country. For cactus the war is an apparatus to achieve his ultimate goal. He makes his intention clear in the following lines:

...our purpose is not only to destroy Behram and his country, but also to strike terror in the hearts of all inferior nations, particularly the proud and independent ones. The magnificent display of our miraculous destructive weapons will delight those who have proper outlook and frighten the ones who have rebellious inclinations (Burning Desert:23)

Zaidi truly expresses her humanistic concern amidst the growing arm race among the nations. Cactus firmly believes that war will be a gateway to enter into the territories of all the inferior nations and consequently to fulfill the actual motive (gold, diamond and oil). Throughout the war he appears to be ruthless dictator using power without giving any kind of consideration to human sufferings. His reign is based on violation and violence, torture and cruelty. He feeds his ego with picture of a devastated nation amidst the 'corpses of men, women and children'. His vaulting desire gets fulfilled by subjugating inferior nations and by indulging in sexual activity with young girls of different nations. The use of sexual imagery (women's' body) is also symbolic of his intention. His excessive sickness for women beauties of different nations reveals his desire to de-sexualize the nations. The offerings of young beauties by different kings are also symbolic of surrendering their nations to Cactus in order to feed his desire. In fact, his allies had to feed his sexual desire as well as his 
material desire. Through the vivid description of sexual imagery, Zaidi encapsulates the colonial myth of white masculinity and black feminity and points out that with the end of colonialism the European fascination of looking at the colonies as female did not die down. Instead, it continued to preoccupy and feed White imagination. Moreover, sexual robbery of the sanctity of the inferior nations also reveals the moral and spiritual breakdown of the West.

Zaidi also shows the diplomatic failure of the United Nations in restraining the Western Nations from indulging into a bloody war with the Middle East nations. This failure has been portrayed through the fictional Peace Council where Cactus authoritatively imposes his whims and desires and consequently forcing the Peace Council to declare Behram as the crusader of world peace order. Cactus knew that his action cannot be justified on humanitarian ground therefore, he need to manage the Peace Council. As a result, Peace Council made Behram responsible for war and strictly ordered him to withdraw from war. In fact, Cactus tactfully institutionalized the so called injustices of Behram through the Peace Council and therefore, he justified his invasion. At the same time he refutes anyone's suggestion to put an end to the war. His three targets - the overthrowing of Behram to gain an access to the natural resources, imposition of New World Order and insight terror among the inferior defying nations - with which he plunged into the war were partially fulfilled. However, as a staunch advocate of world peace and humanism, Zaidi amidst the horrified picture creates the notion that violence and violation and negation of individuality ultimately falls prey to the larger necessity of peace and serenity and mutual co-existence. Therefore, Cactus in spite of his hearted renderings in the war could not attain the desired result. He could not gain the permanent confidence of his allies, the common men came to know his actual motive, and at the end he could not behead his enemy Behram. The only thing he managed to do was mass level devastation, bloodshed, killing and destruction. However, Zaidi also gives a prophetic message that ruthless violence and inhumanity would prevail in this world so long as the Western nations drop their idea of diplomatic imperial control of the weaker nations. Gogo and Didi rightly point out that there is not one Pozzo and Lucky but many who are born from time to time. Both of them give the war and its parties a religious tincture:

Gogo: Oh my God! What will happen then?

Didi: Malicious cruelty will surpass itself, but at the last the blood of innocent people will assert its supremacy - as it happened in Karbala.

Gogo: In Karbala.......?

Didi: Yes, don't you remember the great tragedy of Karbala in which Imam Hussain, who had challenged the corrupt and immoral regime of King Yazid, after a memorable Jihad, finally embraced martyrdom along with his loyal friends and relatives.

Gogo: Why, of course, I remember every bit of it. Don't you know that Imam Hussain, along with Jesus Christ has always been my greatest ideal - . But you can't compare Behram with Imam Hussain.

Didi: No, I'm not comparing Behram with that greatest of all saints and Martyrs. But you can very well compare his adversary - Emperor Cactus - with Yazid and Shimar (Burning Desert:113)

In Burning Desert the character of Cactus is kind of reflection of modern time. The world has failed to lead the society in the right direction. Amidst the idea of democracy, liberalism and multiculturalism, the idea of neo-colonialism has taken deep root. The modern man has fallen prey to the dogmas, power politics and unbridled greed for resources. The race for power has debased the individual and has aroused a sense of detachment and disassociation from the problems and sufferings of fellow human beings. In this regard, Burning Desert reveals the hidden danger of the modern world where cactus is born sometimes out of excessive greed for power as in the case of Cactus, sometimes out of injustices as that of Behram and many such circumstances.

\section{Reference:}

[1]. Mills, Sara (2005). Michael Foucault, New York: Routledge.

[2]. Zaidi, Zahida (1998). Burning Desert. Aligarh: Aabshar Publication (All the subsequent references to the Burning Desert are to this edition) 